\title{
Primary Thyroid Maltoma: A Rare Case Report
}

\author{
Mohd Junaid Ansar ${ }^{1}$, Megha Tandon ${ }^{1 *}$, Niranjan Kumar ${ }^{1}$, Meghraj Kundan ${ }^{1}$, Chintamani ${ }^{1}$, and Amit Yadav ${ }^{2}$ \\ ${ }^{1}$ Department of General Surgery, Vardhman Mahavir Medical College and Safdarjung Hospital, India
}

${ }^{2}$ Department of Pathology, Vardhman Mahavir Medical College and Safdarjung Hospital, India

Received: July 14, 2019; Published: July 29, 2019

*Corresponding author: Megha Tandon, Department of General Surgery, Vardhman Mahavir Medical College and Safdarjung Hospital, New Delhi, India

\section{Introduction}

Primary thyroid lymphoma is very rare. It is defined as lymphoma involving the thyroid gland or the gland and regional lymph nodes with no metastasis of other areas at the time of diagnosis [1]. Primary involvement of thyroid is very rare, and it usually arises in immunologically abnormal gland in background of lymphocytic thyroiditis [2]. Malignant lymphoma constitutes $1 \%-3.5 \%$ of all the thyroid malignancies [3]. Extra nodal marginal zone B-cell lymphoma mucosa associated lymphoid tissue (MALT Type) usually occurs in mucosa of gastrointestinal tract. They may arise in salivary glands, lungs, skin and another site including thyroid. Because of the coexistence of neoplastic and reactive processes in thyroid, there may be difficulty in diagnosing maltoma using cytology and histology. Immunohistochemistry (IHC) and flowcytometry techniques are required to confirm the diagnosis of maltoma [2].

\section{Case Report}

An eighty-three years old lady presented with swelling in front of neck for duration of around 2 years and difficulty in breathing for 2 months. The swelling was insidious in onset and gradually progressive with no associated pain or weight loss however history of orthopnea was present. There was no significant family history or other co-morbidities. On general physical examination there was kyphosis at cervico-dorsal spine. On local examination there was diffuse swelling of both the thyroid lobes with nodular surface and firm consistency with retrosternal extention. No features of hypo- or hyperthyroidism were present. The systemic examination was normal.

Ultrasonography revealed diffuse enlargement of bilateral thyroid lobes with retrosternal extention. Fine needle aspiration cytology revealed lymphocytic thyroiditis. CECT neck showed diffuse enlargement of bilateral thyroid extending into retrosternal space with internal areas of heterogeneously hypoattenuation with differential enhancement and calcification causing mass effect with compression of trachea (Figure 1).

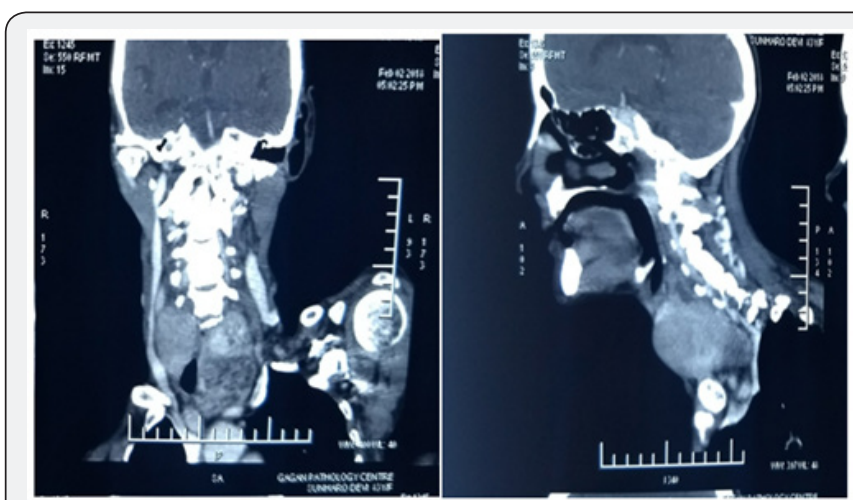

Figure 1: CECT image showing diffuse enlargement of bilateral thyroid lobes with retro-sternal extension and compression of trachea.

The patient underwent total thyroidectomy. Gross examination of resected thyroid revealed two lobes of thyroid measuring $8 \times 5 \times 4 \mathrm{~cm}$ and $7.5 \times 5 \times 3 \mathrm{~cm}$ and isthmus measuring $2 \times 1 \mathrm{~cm}$. External surface is congested and nodular. On cut sections, grey white nodular areas were present with focal areas of hemorrhage. Microscopic sections examined showed thyroid tissue with diffuse infiltration by sheets of plasma cells and lymphocytes in between lymphoid follicles. Immunohistochemistry studies performed with a panel of monoclonal antibodies directed against different cluster of differentiation (CD) antigens and neoplastic cells were positive for CD20, kappa and LCA and negative for CD3, NSE, Synaptophysin, Chromogranin, Calcitonin and lambda. Final diagnosis was extranodal marginal zone B-cell lymphoma with plasmacytic differentiation of thyroid (also known as MALT lymphoma with plasmacytic differentiation).

\section{Outcome and Follow up}

Post-op recovery was uneventful. Considering her age, no chemo- or radiotherapy was given to her. She is in regular outpatient follow-up with no evidence of recurrence for six months (Figures 2-4). 

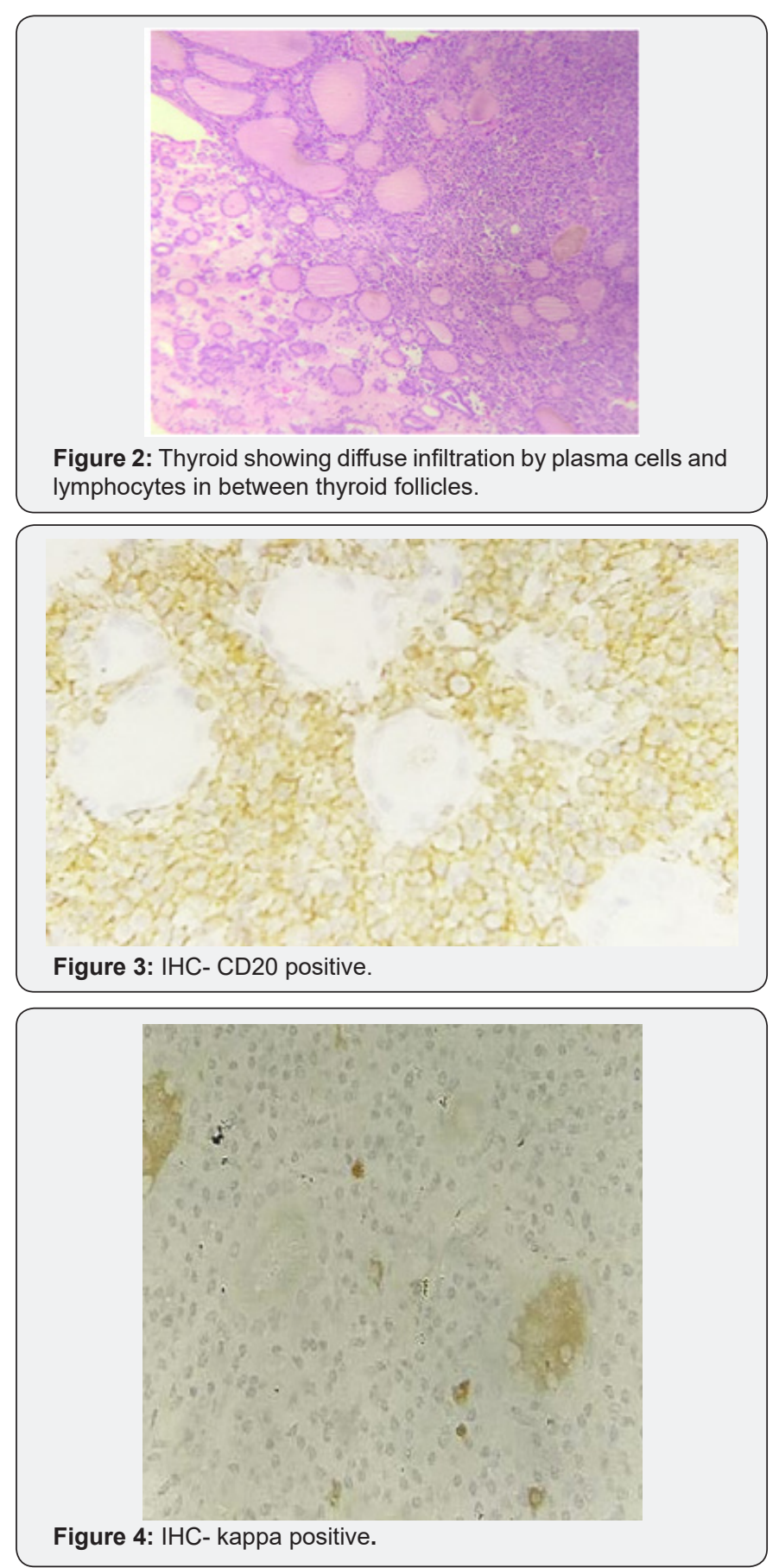

\section{Discussion}

Maltoma usually arise in the tissues affected by the chronic inflammatory process of infectious or autoimmune aetiology. Appearance of extranodal marginal zone lymphomas in chronically inflamed tissues suggest that they arise on a continuum between reactive lymphoid hyperplasia and full- blown B-cell lymphoma. As a result of chromosomal aberration and mutation, a monoclonal neoplasm arises in the background of lymphoid hyperplasia [4]. Thyroid gland does not contain lymphoid tissue. Intra thyroid lymphoid tissue is acquired in the course of autoimmune thyroid disease, notably Hashimoto's thyroiditis. This acquired lymphoid tissue can evolve to lymphoma, including MALT type [5].

Since the introduction of MALT type lymphomas by Isaacson and Wright in 1983, various extranodal locations including thyroid have been described. Histologically thyroid maltomas are characterized by the presence of atypical lymphoid cells originate within marginal zone of lymphoid follicles and can extend into interfollicular space and into the germinal centers [6-7]. MALT lymphomas express B-cell associated antigens CD20, CD22 and CD79a and are negative for CD3, CD5 and CD10 [8].

Maltomas are slow growing lymphomas. Most patients are asymptomatic as the disease remains localized for a long duration. The diagnosis is confirmed only with histopathology and immune-histochemistry. Surgery is done when the pressure symptoms are present or when diagnosis is in doubt if FNAC is inconclusive. The optimal treatment and follow-up of the patients of thyroid maltomas remains controversial at present. The usual treatment is chemotherapy for disseminated disease and radiotherapy for localized disease [2,4-5].

\section{References}

1. Ansell SM, Grant CS, Habermann TM (1999) Primary thyroid lymphoma. Sem Oncol 26: 316-323.

2. Wozniak R, Beckwith L, Ratech H, Surks MI (1999) Maltoma of the thyroid in a man with Hashimoto's thyroiditis. J Clin Endocrinol Metab 84(4): 1206-1209.

3. Thieblemont C, Mayer A, Dumontet C (2002) Primary thyroid lymphoma is a heterogeneous disease. J Clin Endocrinol Metab 87: 105-111.

4. Robbins, Cotran. Robbins Textbook of Pathology ( $6^{\text {th }}$ Edn).

5. Banu Douan GN, Mustafazkan GN, Karamanoulu Z (2004) Primary thyroid lymphoma arising in the setting of hashimoto's thyroiditis. Turkish Journal of Medical Science 34: 395-398.

6. Isaacson P, Wright DH (1983) Malignant lymphoma of mucosa associated lymphoid tissue. A distinctive type of B-cell lymphoma. Cancer 52(8): 1410-1416.

7. Isaacson PG, Androulakis Papachristou, Diss TC, Pan L, Wright DH (1992) Follicular colonization in thyroid lymphoma. Am J Pathol 141(1): 43-52.

8. Harris NL, Jaffe ES, Stein H (1994) A revised European American classification of lymphoid neoplasms: a proposal from the International Lymphoma Study Group. Blood 84(5): 1361-1392. 

(CC) (i) $\begin{aligned} & \text { This work is licensed under Creative } \\ & \text { Commons Attribution 4.0 Licens }\end{aligned}$

DOI: 10.19080/OAJS.2019.10.555799

\section{Your next submission with Juniper Publishers will reach you the below assets}

- Quality Editorial service

- Swift Peer Review

- Reprints availability

- E-prints Service

- Manuscript Podcast for convenient understanding

- Global attainment $f$ or your research

- Manuscript accessibility in different formats ( Pdf, E-pub, Full Text, Audio)

- Unceasing customer service

Track the below URL for one-step submission https://juniperpublishers.com/online-submission.php 